\title{
1. An Overview of the 2013 Federal Election Campaign: Ruinous politics, cynical adversarialism and contending agendas
}

\author{
Jennifer Rayner and John Wanna
}

It was often suggested in the Australian media that the 2013 federal election campaign began effectively on 30 January 2013, when the then-Prime Minister Julia Gillard took the unprecedented step of announcing the election date in a speech to the National Press Club eight months out from polling day. Others may suggest that the campaign truly began when Kevin Rudd returned to the prime ministership on 26 June after a bitter war of attrition within his party. But looking back on how the election unfolded, it seems clear that the campaign began in earnest three years earlier on 7 September 2010, when the Greens and three key independent MPs sided with Labor to deliver Australia its first hung parliament since 1943. That was the day that Tony Abbott's Coalition, with one more seat than Labor in the House, began its tireless crusade to bring down the Gillard, and for the following three years it rarely wavered in this aim.

Viewed in this light, the events of an intensively clamorous election year begin to make sense. The ALP spent much of 2013 looking for a tipping point that would reverse Tony Abbott's steady and inexorable march towards The Lodge, and allow it to break free from a constrictive political agenda set by the Coalition. This search led to a confused and nerve-racking year of activity for Labor which culminated in the displacement of Julia Gillard and the reinstalling of Kevin Rudd to the leadership, followed by a chaotic campaign which seemed to veer from one eccentric policy announcement to the next without any coherent or unifying theme.

By contrast, the Coalition sought to minimise the chances of a turning point occurring by sticking with its tried-and-tested techniques of the past few years: simple slogans backed by scant policy, ruthless discipline to maintain party unity, a highly adversarial focus on three wedge issues and an unrelenting emphasis on the Government's failings. Having framed the election as a referendum on Labor's past six years in office and having set the criteria against which its performance would be (unfavourably) judged, the Coalition arguably needed to do little else but stay the course for victory, while guarding against any hint of overconfidence. 
We explore how this dynamic evolved throughout the years and months leading up to election day 7 September 2013, and what the Coalition's victory demonstrates about the enduring importance of agenda-setting, framing and issue ownership in political campaigning. These analytical frames help to indicate how political leaders and parties come to define or 'own' issues in ways which enhance their strategic advantage relative to their competitors and shape popular understandings (Dery 2000; Harris, Fury and Lock 2006). Agendasetting explores how political actors shape the public discourse and issue agenda; framing and issue ownership involve the selective emphasis of information 'to promote a particular problem definition, causal interpretation, moral evaluation and/or treatment recommendation' (Entman 1993: 52). The key point is that the way leaders talk about issues inherently shapes how they are understood by the public and the range of actions considered feasible in response, and this provides parties with an important strategic tool during election campaigns.

\section{Legacies of the Labor government 2007-13}

The roots of the Coalition's successful agenda-setting and framing efforts were planted in the rather fertile political soil provided by the Labor Government's six years in office, and so it is necessary to look back to the period leading up to the 2010 election to identify their first green shoots.

After barnstorming to power in 2007 with an ambitious agenda for change and political renewal, the Rudd Government quickly found itself mired in the global financial crisis and struggling to deliver promised reform on a wide range of policy fronts. To avoid a recession, the Government worked fast in producing five major stimulus packages between October 2008 and February 2009, which included the distribution of $\$ 900$ cheques to low-paid Australian taxpayers and massive new spending on school and housing infrastructure. While the nation avoided recession as a result of these stimulus measures, the speed with which they were implemented led to instances of amateurishness, poor administration, swindling and even deaths - four young men died in separate incidents while installing roof insulation under a stimulus scheme to improve home energy efficiency. The Coalition began to attack the Government's supposed profligacy and irresponsibility in implementing the stimulus programs. Senior Coalition figures such as Christopher Pyne, Joe Hockey and Julie Bishop used Question Time and the media to continually bait the Rudd ministry about its 'pink batts fiasco' and 'school hall rip-offs', and framed the stimulus spending as the latest example of a panicky Labor Government squandering the surplus built up by its more prudent Liberal predecessors (see Bishop 2008; Hockey 2009; Pyne 
2009). As a consequence, the Government received little credit for the enormous achievement of avoiding recession, while also acquiring the beginnings of a reputation for chaotic policy delivery and poor economic management.

Labor's first term affected the Government in other damaging ways. To expedite decision-making during the financial crisis, Rudd centralised decision-making around a kitchen cabinet of four senior ministers: himself, his deputy Julia Gillard, Treasurer Wayne Swan and Finance Minister Lindsay Tanner. However, these arrangements did not end once the threat of economic doom receded, and the rest of cabinet was increasingly excluded from important policy decisions (Tingle 2010; Tanner 2012). At the same time, Rudd began to irritate his back bench caucus members over the lack of consultation and his chaotic governing style (McKew 2013).

By 2009 - still only its second year in office - the Government appeared to be losing its way, making erratic decisions and failing to address important issues of policy implementation. Rudd stumbled dramatically over policies to mitigate climate change, failing twice to introduce a carbon emissions trading scheme and then shelving further plans to address this critical policy issue in the face of public discontent over projected cost of living increases. One of the Coalition's cut-through campaign messages of 2013 which tagged Kevin Rudd as 'Captain Chaos' had its genesis in this earlier period, when it seemed as though the energy and enthusiasm of 2007 had acquired a more manic edge.

Events came to a head when Rudd was dramatically ousted as leader in June 2010 by Julia Gillard at the behest of Labor's powerful factions. Becoming Prime Minister after the sudden 'coup', Gillard struggled to make an impression from the outset and at the August 2010 election Labor was reduced to minority government status. ${ }^{1}$ Gillard managed to patch together a loose 'coalition' of sorts, denying the Liberals a victory after 17 drawn-out days of negotiation. Almost from the moment that the minority Government was formed, Abbott began describing it as a 'bad government' mired in 'chaos', headed by a woman offering nothing but 'broken promises' who was 'beholden to the Greens'. This depiction of Gillard's Government as weak, unstable and chaotic became a familiar Coalition trope throughout the following three years - Hansard alone records more than 400 instances of Liberal and National MPs using the four phrases highlighted above between 7 September 2010 and the last sitting of parliament in 2013 (Hansard, 43rd Parliament of Australia).

In addition to casting a negative frame around the concept of minority government, the Coalition also chiselled away at Labor's policy credibility by ensuring that three issues stayed at the top of the political agenda: the

1 The ALP narrowly won the two-party-preferred vote at 50.12 to 49.88 per cent, but actually won one fewer seat than the Coalition with 72 to 73 seats respectively. 
economy, asylum seekers and the carbon tax. These issues had been emphasised prominently in the Coalition's 2010 election campaign, and Abbott refused to relinquish them once back in opposition, cementing his 'ownership' of them politically (Newspoll 2013a). During the three years of the Gillard Government, 64 per cent of all opposition questions asked during Question Time were about these same three issues, while Abbott and his shadow ministers also issued hundreds of media releases, briefings, advertisements and even billboards drawing attention to them. The Coalition's framing of these issues was unambiguously negative: a rise in the number of asylum seekers arriving by boat was presented as a 'border security disaster', the fiscal situation and escalating public debt attained the status of a 'budget emergency', and the carbon tax which Abbott promised to 'axe' was blamed for 'driving up the price of electricity bills by $\$ 300$ a year' and 'ripping the heart and soul out of small business' (see Hockey 2013; Abbott and Hockey 2011; Morrison 2011). ${ }^{2}$ The thrashing of these core issues advantaged the Coalition while it highlighted the stark tension between the party's traditional, materialist support base and its more recent, post-materialist one (Charnock and Ellis 2004). It also provided the opportunity for the Opposition to hammer Labor for placing environmental issues ahead of the cost of living concerns of ordinary voters.

The Gillard Government worked conscientiously to pursue its own distinct policy agenda, committing to a major overhaul of education funding, developing the National Disability Insurance Scheme and accelerating the roll-out of the National Broadband Network, amongst other achievements. But in the face of the Coalition's relentless aggression, Labor seemed unable to gain traction with its alternative agendas. ${ }^{3}$ Gillard spent a significant proportion of her term talking about Coalition-owned issues and her opponent's agendas. This suggests the Government was continually reinforcing both the salience of these issues as benchmarks of governing competence, and the Coalition's ownership of them in the eyes of voters (Walgrave, Lefevere and Nuytemans 2009).

Labor seemed unable to move the public conversation past the Coalition's favoured issues, and struggled to neutralise Abbott's negative framing of them. On occasions the Government appeared to play right into his hands. For instance, Treasurer Wayne Swan spent over two years steadfastly promising to deliver a budget surplus by mid-2013 before unceremoniously ditching this commitment in December 2012 - a backflip which only served to reinforce the Coalition's

2 It also allowed the Coalition to mount an effective personal attack on Gillard as a 'liar', 'hypocrite' and 'untrustworthy' head of government.

3 To give an illustration of this, between August 2010 and June 2013 we identified 5,332 articles in Australia's capital city newspapers which featured Gillard discussing asylum seeker issues, 4,713 discussing her Government's management of the economy, and 4,567 focusing on the carbon tax. By contrast, the same papers published 3,853 articles which featured Gillard discussing her party's education agenda, 1,314 on the National Broadband Network, and just 904 on the National Disability Insurance Scheme. Search conducted via Ebsco Host Australia New Zealand Reference Centre, hosted by the National Library of Australia. 
claim Labor could not manage the country's finances effectively. Similarly, the Government pursued a range of measures to manage asylum seekers which foundered in the implementation and did not stop arrivals, and so lent weight to Abbott's rhetoric about the Government failing to 'stop the boats'. On the carbon tax, the Government attempted to neutralise the Coalition's negative frame and provide a more positive one by positioning the tax as a necessary response to global warming and a sign of Australia's good global citizenship. However, the Government's frame was relatively academic and thematic in that it relied upon theoretical claims about environmental benefits and comparing the Australian scheme against international benchmarks (Gillard 2011; Combet 2011). By contrast, the Coalition's frame was almost entirely episodic, as it appeared to have an endless supply of anxious pensioners and frustrated small business owners to trot out as evidence of the tax's negative effects (see Abbott 2012; Abbott 2011; Hunt 2013). The personal content of episodic frames gives them far greater emotional resonance and endurance than thematic ones (Aarøe 2011), which perhaps helps to explain why the Gillard Government was not successful in re-framing this damaging political issue.

During the period of minority government, Labor was also wrestling with the internal consequences of sacking Kevin Rudd and exiling him to the back bench. On this issue the Coalition needed to do little except stand back and allow voters an unimpeded view of Labor's cannibalisation. Deeply resentful at being ousted from office and determined to regain the nation's top job at any cost, Rudd first challenged Gillard in late February 2012. Resoundingly losing that ballot, Rudd continued to agitate against Gillard behind the scenes, prompting a bungled 'non-coup' in March 2013 when his backers pushed him to challenge again but he ultimately chose not to stand (Wanna 2013: 620-1). Recognising that unity and stability would be an asset when contrasted with Labor's internal toxicity, the Coalition took pains to emphasise the party's 'strong and united leadership team' during this period. Abbott kept reminding voters that his shadow front bench had remained unchanged since he assumed the leadership in 2009 (with potential aspirants such as Malcolm Turnbull remaining firmly 'within the tent'), in sharp contrast with the five ministerial re-shuffles necessitated by Labor's in-fighting.

As a result of these tumultuous contextual events, the Labor Government entered the election year with its public standing at record lows, a reputation for chaos, division and inconsistency, and a policy agenda littered with unresolved issues which favoured its opponents. By contrast, the Coalition commenced the year with a strong and unified team, a simple and consistent set of messages that it had repeated ad nauseum for the previous three years, and a rhetorical set of solutions to the policy issues it worked so diligently to keep on the political agenda. With the momentum clearly running its way, the Coalition simply 
needed to ensure that nothing would alter the electoral playing field. The Government, on the other hand, urgently needed to find some way to level it in order to be competitive.

\section{The longest campaign before Labor's caucus finally capitulates to Rudd}

In desperation, Labor attempted the first of its 'game-changing' moves on 30 January, when Prime Minister Gillard took the unprecedented step of announcing the election date for 14 September - then some eight months away. Traditionally in Australian politics, governments guard the election date closely and attempt to spring it on their opponents at a strategically advantageous moment. But by giving away that small advantage, Gillard apparently hoped to demonstrate that she was in control of the political agenda and pressure the Coalition into revealing the details of the policies it had been touting for the previous three years (Rayner 2013). There was much speculation that her announcement was aimed at discouraging the Rudd forces from mounting any further challenges and forcing the party to lock in behind her for the campaign (Grattan 2013; Wanna 2013).

Gillard's gamble in foreshadowing the election date so early did not succeed on any of these counts. Remembering Paul Keating's demolition of John Hewson's detailed Fightback! package in 1993, ${ }^{4}$ the Coalition refused to rise to the bait and release its costings or detailed plans, denying ammunition to the Government with which it might attack the Opposition's credibility. Despite the Government not being in formal caretaker mode, Gillard also found it increasingly difficult to progress her own political agenda on issues such as the Gonski schools funding package, disability care and media reform because many of the key stakeholders decided to 'dig in' and wait for the expected change of government rather than engage in constructive negotiations with Labor (Coorey et al. 2013; Hywood 2013; Shanahan 2013; Williams 2013).

Furthermore, in the last days of the last parliamentary sitting week, the querulous Rudd forces rallied again for a final tilt and convinced a narrow majority of the nervous caucus to support his leadership bid. This was a lastditch effort to minimise Labor seat losses after independent polling showed the Government could lose up to 24 marginal seats - one-third of its representation in the lower house of parliament. The party appeared to believe that returning

4 Tony Abbott was Hewson's press secretary at the time and so had a vivid, first-hand experience of the sport that governments can make with opposition policy. 
to Rudd would put it back in the game electorally by drawing a line under the negativity of the minority government and neutralising the personal animosity towards Gillard (the so-called 'save the furniture' strategy).

In the caucus ballot Rudd received 57 votes but Gillard still managed 45 votes from her ardent loyalists and, significantly, carried most of her ministers with her. Reactions to Labor's revolving leadership circus went from relief from Labor pragmatists who felt the change gave them better campaign prospects (Hawker 2013), to some belated praise for Gillard as Australia's first female prime minister and condemnation for those who had sought to bring her down. To the electorate, the reinstallation of Rudd reinforced the impression that Labor was inherently unstable and 'unworthy' to govern, and so the leadership switch did not appear to alter the electoral dynamic substantively (Newspoll 2013b). Labor's persistent disunity and dysfunctionality would remain a powerful factor in the election campaign (Wright 2013).

While the Government was wrestling to deliver its policy agenda and manage Labor's internal ructions, the Coalition simply stepped up the pace of its longrunning campaign while maintaining consistency in its form and content. Abbott began the year by releasing the party's election policy summary on Australia Day, and then embarked on a 'mini-campaign' in the key eastern states to promote this plan. The policy summary entitled Our Plan: Real solutions for all Australians contained all of the party's signature policies which had been announced since 2010, including a generous paid parental scheme, abolishing the carbon tax and replacing it with a Direct Action Plan to cut carbon emissions, stopping the asylum seeker boats and restoring the budget to surplus (Liberal Party of Australia 2013). But despite these policies having been developed years in advance, the Coalition did not include any substantive detail on their implementation in the campaign document. Abbott also resisted pressure to release the party's costings until the second last day of the formal campaign. The Coalition seemed to understand that the detail of its policies was not as important as the symbolism of having a plan, in sharp contrast with Labor's apparent lack of direction. Importantly too, the Coalition's continued focus on an already-announced agenda lent weight to Abbott's promise to lead a stable, 'no surprises' government (Abbott 2013a).

One lingering negative for the Coalition was Tony Abbott's personal standing with the electorate, as public polling showed that some segments of the community remained deeply distrustful of him both because of his conservative social and religious views, and his reputation as a political brawler. As Kirsty McLaren and Marian Sawer note in Chapter 22, from the time of the campaign mini-launch in January the party worked to counter this by presenting Abbott as calm, reasonable and moderate in his views; showing him to be 'a daggy dad' rather than a 'dangerous ideologue'. Abbott's wife, daughters, lesbian 
sister and feminist chief of staff were all called into service to demonstrate his good relationships with women and evolving view of issues such as marriage equality and abortion (Australian Women's Weekly 2013; Hayes 2013; Maiden 2013). This came across as a concocted attempt to wear down public resistance to Abbott and remove any final barriers to voting Liberal for soft and swinging voters; some critics claimed that Abbott would not be able to sustain the façade throughout the campaign (Howitt 2013; Smith 2013). While he remained quite unpopular by historical standards, the Liberal Party's charm offensive appeared to be relatively successful in rehabilitating Abbott's image as his approval ratings increased from 29 per cent in January 2013 to 44 per cent by the final week of the campaign (Newspoll 2013c).

Throughout 2013 the public opinion polls such as Newspoll, Nielsen, Morgan and Galaxy were a constant source of good cheer for the Coalition, as they regularly showed the margin between it and the Government fluctuating between 55-45 and 60-40 per cent. On occasion, Labor's primary vote was down to 2931 per cent compared to the Coalition's primary support of 45 per cent, with the two-party-preferred vote holding at 43 per cent to Labor against 57 per cent for the Coalition. Only once during the year-immediately after Rudd's returndid Newspoll show the Government drawing level with the Coalition, and only one of the published polls showed Labor leading at any point during the year (Morgan on 1 July 2013, with Labor at 51.5 to 48.5).

Despite an initial honeymoon, Rudd failed to restore Labor's electoral prospects to the heights the Government may have hoped for. But his return created a brief period of potential advantage which he sought to press by calling the election for 7 September 2013, a week earlier than Gillard had nominated. In the final section, we briefly canvass the key events of the formal campaign and demonstrate how these barely shifted the by then established dynamic between the Government and its opponents.

\section{Fear, loathing and empty slogans on the campaign trail}

Rudd's return hobbled Labor's campaign effort in two significant ways. At a practical level, 110 of the party's 150 campaign staff reportedly quit upon learning of Gillard's ousting by Rudd, leaving Labor scrambling to fill key roles just weeks out from the formal campaign (Wright 2013). Demonstrating his old controlling instincts, Rudd brought in his own team of advisors - including long-time confidant Bruce Hawker - who reportedly operated as a parallel and competing campaign unit to that within the ALP's headquarters (Hawker 2013; Snow 2013). 
More significantly, Rudd's return meant that the ALP could no longer campaign on its signature achievements of the past term: introducing the National Disability Insurance Scheme and progress made on the implementation of the Gonski education funding plan. These major national initiatives were intimately linked with Julia Gillard's prime ministership, and so building the campaign around these would have only served to highlight Labor's rotating leadership. Instead, the party opened its campaign by focusing on national leadership, with Rudd promising 'a better way, a smarter way, a new way to secure Australia's future' (Australian Labor Party 2013). As Sally Young and Nicholas Reece detail in Chapters 6 and 7, the 'New Way' pitch was an obvious throwback to Labor's successful 'New Leadership' campaign of 2007 and an attempt to replace the toxic odour of the minority government with the heady optimism of 'Kevin07'. However, many campaign-watchers commented on the effrontery of Rudd's claim given his central role in the ugliness of the past few years, and so the 'New Way' emphasis on change was quickly dropped (Hartcher 2013).

In its place, Labor opted for a deeply negative attack on the Coalition, accusing it of having a secret 'slash and burn' agenda which would decimate government services, raise the goods and services tax (GST) to 12 per cent, and rip away supports for families such as the School Kids Bonus. Labor's TV advertisements identified Abbott as a cruel fiend who would lead an onslaught against Australian living standards - with the most emphasised slogan being 'If Abbott wins, you lose'. To support this attack, Rudd held a joint press conference with Treasurer Chris Bowen and Finance Minister Penny Wong to announce that they had identified a $\$ 10$ billion 'black hole' in the Coalition's costings which could only be addressed by 'cuts, cuts and more cuts' (Rudd 2013a). The announcement was apparently intended to puncture the Coalition's financial credibility and undermine its claim to offer stable, responsible government. But it backfired spectacularly when the heads of the Treasury and Finance departments publicly declared that their agencies had not been involved in costing the policies and that Labor's figures could not be relied upon (Department of the Treasury 2013). The party was left looking incompetent and more than a little desperate, particularly as Rudd continued to quote the $\$ 10$ billion figure in interviews and campaign speeches. Indeed, cynicism all round about claims and counterclaims made by politicians saw the establishment of a raft of 'fact checker' web sites that variously investigated campaign statements for their accuracy (see Canberra Times 4 September 2013: 24-5).

Aside from its attacks on the Coalition, the Labor campaign lacked a consistent, unifying theme as Rudd's daily announcements ranged over health, jobs, education, infrastructure and much else besides without settling long on any of these issues. In stark contrast with 2007 when every Labor policy was carefully detailed and costed, Rudd made three major announcements which appeared 
to have been thought up on the spot: promising to introduce marriage equality legislation within the first 100 days of a new parliament; proposing to establish a Special Economic Zone in the Northern Territory; and suggesting that Sydney's Garden Island naval base could be relocated to Queensland (Rudd 2013b, 2013c and 2013d). Each of these policies were apparently intended to appeal to specific segments of the community who, together, would build a coalition of support for Labor, while also allowing it to seize the political agenda back from the Coalition. But these policies did not knit into a cohesive plan for a third term of government, or engage with the everyday concerns of soft and swinging voters. Furthermore, the lack of detail and major cost implications firmly reinforced the Coalition's framing of Labor as being immature and reckless at the helm of government.

For the Coalition's part, it simply continued with the course it had planned several years before: highlighting Labor's supposed failings on the economy, its duplicity over the carbon tax, and inability to stem the flow of asylum seekers, while spruiking both the unity and experience of its own team, and the benefits of key commitments such as its generous paid parental leave scheme. Labor's only real response to these issues was to re-intensify its attacks against Abbott, as it had failed to either neutralise these issues or develop effective policy solutions to them over the preceding months. Interestingly, the Coalition did not seek to directly capitalise on Labor's leadership instability or run a character assassination on Rudd - despite having a wealth of archive material available featuring members of Rudd's own party giving their frank assessments of his character. Instead, from the time of Rudd's return to the prime ministership Abbott adopted a weary and slightly incredulous tone when dealing with the issue, and simply called on voters to 'end the soap opera' by voting for 'strong, stable and competent government' (Aston 2013). It was also clear from the body language and verbal jousts at the three public debates that both leaders loathed each other and found it hard to take their opponent seriously.

As has now become customary, both major parties launched their campaigns well inside the formal campaign period and both opted to do so in the battleground state of Queensland - the Coalition two weeks out from polling day on Sunday 25 August, and Labor on 1 September. The launches offered little that was new either in policy or messaging, which was probably just as well because record high early voting meant that many Australians had already cast their ballots by the time these launches were held. According to the Australian Electoral Commission, more than 275,000 people had lodged an early vote by 25 August, and over one million people had done so by 1 September (Australian Electoral Commission 2013a and 2013b). In total, more than 3.2 million Australians voted before polling day in 2013, a significant increase on the 2.5 million who did so in 2010 (Australian Electoral Commission 2013c). As discussed by other 
contributors in more detail in section four, this sharp rise in early voting appears to indicate that voters had made up their minds well in advance and simply wished to get the election over with - something which is supported by the relative consistency of the opinion poll results for both major parties over the preceding year.

As the campaign neared its end, the apparent inevitability of a Coalition victory caused a shift in focus to some of the other players on the electoral field. Perhaps in response to voter dissatisfaction with all participants in the hung parliament, there was an increased prominence afforded to minor and micro parties in the election, although the majority of these parties were single issue groups which only managed to stand candidates for the Senate. They did not receive much attention from the media or major parties until it emerged that Glen Druery, a New South Wales consultant, was engineering a preference-swapping alliance between them to channel support away from the larger parties (Norrington and Lewis 2013). The alliance was ultimately successful in securing the election of micro party senators in every state - an outcome which subsequently led to calls for reform of Australia's compulsory preferential and ticket voting systems. Contesting their first federal elections, Katter's Australia Party and the Palmer United Party also attracted attention for their larger-than-life leaders and unorthodox campaign techniques, but relatively few seasoned observers took either party seriously as a major electoral prospect.

The Australian Greens found themselves hemmed in from all sides in the 2013 campaign, as the Coalition's negative framing of the Gillard minority Government also damaged its minor party supporting partner, while the proliferation of new and special interest parties diminished the Greens' appeal as the party with which to park a protest vote. Furthermore, having gained its first lower house MP in 2010, the party was determined to retain the seat of Melbourne but needed to do so on primary votes as both major parties decided to preference all other candidates before the Greens, including their main antagonists. In an apparent effort to break the association with Labor, the Greens had formally withdrawn from their parliamentary agreement in February 2013 and committed the party to pursuing a different path from either of the major parties (Milne 2013). This was most notably seen in the debate about asylum seekers throughout the year, when the Greens advocated a humanitarian policy which was far more compassionate than those proposed by both the Coalition and the ALP. This arguably assisted Adam Bandt in retaining Melbourne, but appears to have hurt the party elsewhere as its national vote on election day fell back more than three per cent from the 2010 result (Miragliotta 2013). The 'battle for Melbourne' was closely watched in the final weeks of the campaign as it was seen as one of the few opportunities for a Labor gain, but by pouring a reported \$1 million into the seat, the Greens were able to retain the seat. 
A change of government was obvious within hours of the polls closing on election night, and by 10 pm Kevin Rudd had conceded defeat. The atmosphere at his concession speech was somewhat more triumphal than mournful however, as Labor had avoided a feared electoral wipe-out on the scale seen in the previous Queensland and New South Wales state elections. Although Labor had recorded its lowest vote in 100 years, the party ultimately won 55 seats to the Coalition's 90 with all former cabinet members retaining their seats, giving it the resources to be a 'viable fighting force for the future' (Rudd 2013e). Prime Minister-elect Tony Abbott used his acceptance speech to declare that Australia was 'under new management and ... once more open for business' and reiterate his intention to lead a government 'of no surprises and no excuses' (Abbott 2013b). While there would be a few shocks for the Coalition in the final wash-up of counting - frontbencher Sophie Mirabella suffered a nine per cent swing to be defeated by independent Cathy McGowan and Queensland MP Ted O'Brien narrowly lost Fairfax to Clive Palmer - there could be no denying the scale and decisiveness of Abbott's win. It was a calculated gambit largely orchestrated over two consecutive stages - firstly, the 2010 election to even the contest, then the 2013 election to cement the victory. Abbott's triumph was largely one of attrition.

\section{Conclusion}

In looking back at the 2013 federal election it would be easy to explain Labor's 'thumping defeat' as a product of its leadership instability, and the continual changes in policy and focus which flowed from this (Shanahan 2014). Immediately after the election, several Labor figures were quick to suggest this narrative of events, with the outgoing Minister for Health Tanya Plibersek claiming the party deserved ' 9 out of 10 for governing the country [but] 0 out of 10 for governing ourselves' (ABC TV 2013b). There can be no denying that the Labor Government comprehensively allowed its chances of re-election for a third term to evaporate by appearing to spend more time fighting than governing, and certainly this widespread perception explains much about the final result. However, this 'governments lose office' narrative does not give sufficient credit to the Coalition for applying the pressure which so often caused the Government to crack, or for its discipline and strategic nous in leveraging the Government's internal travails to its own advantage.

As we have suggested, the Coalition was largely responsible for focusing attention on three iconic issues and keeping them at the forefront of the political agenda - the economy, asylum seekers and the carbon tax. Each of these issues was damaging to Labor and they were promoted as litmus tests of the Government's incompetence in dealing with policy problems. What's more, Abbott's opposition successfully framed these issues in such a way as to inflict 
maximum political pressure on the Government, often forcing it to adopt policy positions which were unsustainable, unworkable or downright ill-considered. The Coalition under Abbott had the discipline to unite behind a clear and consistent set of themes which connected both to its values and the aspirations of many Australians, and it had the sense to know when to step back and simply allow voters full view of Labor's internal grief. In doing so, the Coalition not only demonstrated the enduring importance of agenda-setting, issue ownership and framing in elections, it also convinced sufficient voters that it did have what it takes to deliver 'grown-up government'. Given the stark contrast this created with Labor, it is hardly surprising that so many Australians opted for change.

\section{References}

60 Minutes. 2013. 'The contender'. Television broadcast, Nine Network, 5 March. Presented by Liz Hayes.

Aarøe, Lene. 2011. 'Investigating frame strength: the case of episodic and thematic frames'. Political Communication 28(2): 207-26.

Abbott, Tony. 2011. 'Questions without notice-carbon pricing'. Hansard, 43rd Parliament of Australia. 28 February.

Abbott, Tony. 2012. 'Questions without notice - carbon pricing'. Hansard, 43rd Parliament of Australia. 10 October.

Abbott, Tony. 2013a. 'Address to the federal campaign rally, Lidcombe'. 27 January.

Abbott, Tony. 2013b. 'Federal Election 2013-victory speech'. 7 September.

Abbott, Tony and Hockey, Joe. 2011. 'Julia Gillard's carbon tax'. Transcript of joint doorstop interview, 1 March.

Abbott, Tony and Rudd, Kevin. 2013. 'Leaders Debate'. National Press Club, 11 August, viewed 14 October 2013: <www.kevinrudd.org.au/latest3_110813>.

ABC TV. 2013. Australia Votes 2013. Television broadcast, 7 September. Interview with Health Minister Tanya Plibersek.

Aston, Heath. 2013. 'Libs rally to end "soap opera"'. Sydney Morning Herald, 29 June.

Australian Electoral Commission (AEC). 2013a. 'Early voting numbers increase as remote and overseas polling starts'. Media release, 27 August, viewed 2 April 2014: <www.aec.gov.au/media/media-releases/2013/e08-27.htm>. 
AEC. 2013b. 'Early voting tracking to record levels as polling day preparations ramp up'. Media release, 5 September, viewed 2 April: <www.aec.gov.au/ media/media-releases/2013/e09-05a.htm>.

AEC. 2013c. 'Key facts and figures - 2013 federal election'. Viewed 20 November: $<$ www.aec.gov.au/Elections/Federal_Elections/2013/files/e2013-key-facts. $\mathrm{pdf}>$.

Australian Labor Party. 2013. A New Way. Campaign advertisement, viewed 18 November: <www.youtube.com/watch?v=WMGCByEkWKA>.

Australian Women's Weekly. 2013. 'Is Tony Abbott a changed man?', 11 March.

Bishop, Julie. 2008. 'Mid-year economic and fiscal outlook'. Transcript of doorstop interview, 5 November.

Budge, Ian and Farlie, Dennis J. 1983. Explaining and predicting elections. London: Allen \& Unwin.

Charnock, David and Ellis, Peter. 2004. 'Postmaterialism and postmodernisation in Australian electoral politics'. Electoral Studies 23(1): 45-72.

Combet, Greg. 2011. 'Questions without notice-carbon pricing'. Hansard, 43rd Parliament of Australia, 12 September.

Coorey, Phil, Whitbourn, Michaela and Mather, Joanna. 2013. 'Labor states join Gonski backlash'. Australian Financial Review, 19 April.

Department of the Treasury. 2013. 'Statement on costings by the Department of the Treasury and the Department of Finance and Deregulation'. Media release, 29 August, viewed 2 April 2014: <www.treasury.gov.au/ PublicationsAndMedia/MediaReleases/2013/Costings-Statement $>$.

Dery, David. 2000. 'Agenda setting and problem definition'. Policy Studies 21(1): 37-47.

Entman, Robert M. 1993. 'Framing: towards clarification of a fractured paradigm'. Journal of Communication 43(4): 51-8.

Gillard, Julia. 2011. 'Questions without notice - carbon pricing'. Hansard, 43rd Parliament of Australia, 1 March.

Grattan, Michelle. 2013. 'Well executed? Or executed well?' The Age, 31 January.

Hansard. 2010-13. Parliamentary Debates of the 43rd Australian Parliament 2010-2013. Canberra: Parliament of Australia. 
Harris, Phil, Fury, Donna and Lock, Andrew. 2006. 'Do political parties and the press influence the public agenda?' Journal of Political Marketing 5(3): 1-28.

Hawker, Bruce. 2013. The Rudd Rebellion: the campaign to save Labor. Melbourne: Melbourne University Press.

Hayes, Danny. 2008. 'Party reputations, journalistic expectations: how issue ownership influences election news'. Political Communication 25(4): 377-400.

Hockey, Joe. 2009. 'Cloud of debt hangs heavy'. The Sun Herald, 6 September.

Hockey, Joe. 2013. Address to the Australian Mines and Metals Association National Conference'. Melbourne, 17 May. Transcript available online, viewed 1 April 2014: <www.joehockey.com/media/speeches/details.aspx?s=116>.

Howitt, Clint. 2013. 'The polishing of Tony Abbott'. Independent Australia, 25 May, viewed 17 November 2013: <www.independentaustralia.net/2013/ politics/tony-abbott-as-prime-minister/>.

Hunt, Greg. 2012. 'NSW power bills skyrocket due to carbon tax'. Media release, 13 June, viewed 2 April: <www.liberal.org.au/latest-news/2012/06/13/nswpower-bills-skyrocket-due-carbon-tax-0 $>$.

Hunt, Greg. 2013. 'Questions without notice - carbon pricing'. Hansard, 43rd Parliament of Australia, 20 March.

Hywood, Greg. 2013. Evidence before the Environment and Communications Legislation Committee inquiry into the Public Interest Media Advocate Bill 2013, 18 March. Canberra: Parliament of Australia.

Lateline. 2013. 'Opposition leader's image'. Television program transcript, ABC, 30 April, viewed 1 April 2014: <www.abc.net.au/lateline/content/2013/ s3748802.htm>. Reporter Suzanne Smith.

Liberal Party of Australia. 2013. Our Plan: Real solutions for all Australians. Canberra: Liberal Party of Australia.

Maiden, Samantha. 2013. 'With Tony Abbott on my side'. The Sunday Telegraph, 6 January.

McKew, Maxine. 2013. Tales from the political trenches. Melbourne: Melbourne University Press.

Milne, Christine. 2013. 'Address to the National Press Club'. Canberra, 19 February. 
Miragliotta, Narelle. 2013. 'Election 2013 brings a mixed result for the Greens'. The Conversation, 9 September, viewed 19 November 2013: < theconversation. com/election-2013-brings-a-mixed-result-for-the-greens-17524>.

Morrison, Scott. 2010. 'Business as usual for people smugglers under Gillard'. Media release, 5 October, viewed 2 April 2014: <www.liberal.org.au/latestnews/2010/10/05/business-usual-people-smugglers-under-gillard-0 $>$.

Newspoll. 2013a. Political and issues trends. Best party to handle federal issues. Summary 9-11 August 2013, viewed 19 November 2013: <polling.newspoll. com.au/image_uploads/130803\%20Issues.pdf $>$.

Newspoll. 2013b. Political and issues trends. Federal voting intention. 11 to 13 January-9 to 11 August, viewed 19 November 2013: <www.newspoll.com. au/opinion-polls-2/opinion-polls-2/>.

Newspoll. 2013c. Political and issues trends. Satisfaction with leader of the opposition. 11 to 13 January-9 to 11 August, viewed 19 November 2013: $<$ www.newspoll.com.au/opinion-polls-2/opinion-polls-2/>.

Norrington, Brad and Lewis, Rosie. 2013. 'Minor parties pay consultant to engineer preference swap deals'. The Australian, 4 September.

Petrocik, John R, Benoit, William L and Hansen, Glenn J. 2003. 'Issue ownership and Presidential campaigning, 1952-2000'. Political Science Quarterly 118(4): 599-626.

Pyne, Christopher. 2009. 'School hall building program falling down'. Media release, 14 June, viewed 2 April 2014: <www.pyneonline.com.au/media/ media-releases/releases $>$.

Rayner, Jennifer. 2013. 'In an escalating political arms race, Gillard blinks first'. The Drum, 30 January 2013, viewed 15 November 2013: <www.abc.net.au/ unleashed/4491676.html>.

Riker, William H. 1986. The art of political manipulation. New Haven: Yale University Press.

Roy Morgan Research. 2013a. 'Morgan Poll: Rudd pushes ALP ahead of L-NP'. The Monthly, I July, viewed 9 October 2013: <www.themonthly.com.au/ blog/roy-morgan-research/2013/07/01/1372660748/morgan-poll-ruddpushes-alp-ahead-l-np>.

Roy Morgan Research. 2013b. 'Morgan Poll-Parties locked at 50/50 after week one'. The Monthly, 12 August, viewed 9 October 2013: <www.themonthly. com.au/blog/roy-morgan-research/2013/08/12/1376262827/morgan-pollparties-locked-5050-after-week-one>. 
Rudd, Kevin. 2013a. '\$10 billion error in the Opposition's savings'. Transcript of joint press conference, 29 August.

Rudd, Kevin. 2013b. 'Growing the North: a plan for Northern Australia'. Media release, 15 August, viewed 2 April 2014: <d3n8a8pro7vhmx.cloudfront.net/ australianlaborparty/pages/995/attachments/original/1376694666/MR_-_ Growing_the_North.pdf $>$.

Rudd, Kevin. 2013c. 'Deploying Australia's Navy to secure our nation'. Media release, 27 August.

Rudd, Kevin. 2013d. 'Kevin Rudd's concession speech'. Australian Labor Party, 7 September, viewed 1 April 2014: <www.alp.org.au/kevin_rudd_s_ concession_speech>.

Rudd, Kevin. 2013e. 'Address to Caucus' , Canberra, 13 September, viewed 23 December 2014: <australianpolitics.com/downloads/alp/13-09-13_addressto-caucus_kevin-rudd2.pdf $>$.

Shanahan, Dennis. 2013. 'Campbell Newman joins Gonski revolt as Queensland threatens June deadline'. The Australian, 3 June.

Snow, Deborah. 2013. 'How Kevin Rudd's 2013 election campaign imploded'. The Sydney Morning Herald, 9 September.

Tanner, Lindsay. 2012. Politics with purpose: occasional observations on private and public life. Melbourne: Scribe Publications.

Walgrave, Stefaan, Lefevere, Jonas and Nuytemans, Michiel. 2009. 'Issue ownership stability and change: how political parties claim and maintain issues through media appearances'. Political Communication 26(2): 153-72.

Wanna, John. 2013. 'Utter despondency over Labor's leadership woes'. Australian Journal of Politics and History 59(4): 618-25.

Williams, Kim. 2013. Evidence before the Environment and Communications Legislation Committee inquiry into the Public Interest Media Advocate Bill 2013. 18 March. Canberra: Parliament of Australia.

Wright, George. 2013. 'Address to the National Press Club'. Canberra, 29 October, viewed December 2013: <d3n8a8pro7vhmx.cloudfront.net/ australianlaborparty/pages/1890/attachments/original/1383017072/George_ Wright_Address_to_NPC_Transcript.pdf $>$. 
This text taken from Abbott's Gambit: The 2013 Australian Federal Election, edited by Carol Johnson and John Wanna, published 2015 by ANU Press, The Australian National University, Canberra, Australia. 